Journal of Southeast Asian Human Rights, Vol. 5 Issue. 1 Jume 2021 pp. 84 - 93

doi: 10.19184/jseahr.v5i1.24891

(C) University of Jember \& Indonesian Consortium for Human Rights Lecturers

\title{
Book Review: Editor: Al Khanif and Dina Tsalist Wildana; Title: Kebebasan Beragama atau Berkeyakinan di Indonesia; Publisher: Intrans Publishing, 2020
}

\author{
Hery Prasetyo \\ Departement of Sociology, University of Jember \\ Email: Herypras.fisip@unej.ac.id
}

\begin{abstract}
The book entitled "Kebebasan Beragama atau Berkeyakinan di Indonesia: Perspektif Filosofis, Hukum dan Politik" explains the complexity of the rights of adherents of religion or beliefs in the era of democracy in Indonesia. What is important to note is whether there is freedom of religion or belief in Indonesia. Social scientists may find it difficult to determine the dimensions of freedom and obedience because in philosophy, for example, freedom and obedience are often contradicted as part of the existentiality of thought. However, in practice, especially in the context of the life of a nation-state, the discourse of freedom and obedience requires theoretical and empirical exploration to form a multicultural society. In this corridor, editors and book writers spread their knowledge as intellectuals and as a form of taking sides on human rights issues. However, sociologically it should be noted that freedom is not a fixed social condition. The dynamics that accompany the emergence of religious adherents should be of public interest so that the knowledge of civil society is filled with emancipatory spirit. Yet, the author finds the opposite condition, where the prerequisites for creating multiculturalism are far from democratic principles. Freedom is still framed legally formally and contradicted as if there is only one absolute truth. In this case, the argument that multiculturalism is a value worth fighting for becomes a barrier because diction has lost its supporting power. Not only because religious sentiment has developed into identity politics but also turned into a different imagination about Indonesia. Of course, the presence of this book is not intended to eliminate the current problems or even to emphasize the channels of difference. On the other hand, reading this book is a challenge to revive the spirit of multiculturalism with a frame of freedom that is a shared responsibility.
\end{abstract}

This article reviews and may even be viewed as a comment to the book entitled "Freedom of Religion or Belief in Indonesia: Philosophical, Legal, and Political Perspectives," edited by Al Khanif and Dina Tsalist Wildana. The book contains of 222 pages of scientific paper published by Intrans Publishing. Six writers contributed and highlight issues relating to Freedom of Religion and Belief. It begins with 
philosophical discourse then moving on to legal and political issues. Each article is cannot inseparable from others in the context of seizing the human rights discourse in Indonesia. Therefore, this book becomes important to address school of thought of human rights as a part that should be discussed philosophically to the legal dimensions and political dynamics that accompany the emergence of cases of violations of the rights of religion and belief.

In advance to discuss the issues elaborated by each author in the book, first is needed to explore the discourse of human rights (HAM) presented in daily activities. Indonesian citizens, especially those who live in the new order era, generally interpret human rights as matters relating to the authority of the state. ${ }^{1}$ In other words, the interpretation and practice of human rights are determined by centralized power. The separation between public affairs, a matter within the responsibility of the State, and private affairs as part of the articulation of the needs and interests of citizens develops into a discourse that leaves no space for dialogue. ${ }^{2}$ The conflict between the public and private is framed in development projects, where the government emphasizes that the mainstreaming of state interests cannot be replaced by individual needs. Furthermore, the State has positioned itself in a space that criticism is unable to touch it. As such, 'freedom of speech' remains controlled by the State, as the Master of Public discourse.

The post-reformation era interrupts the monotonous conformity of social space, facilitating the emergence of a new, dynamic character, complemented by freedom of expression. This social shift raises the question: is the celebration of freedom of speech followed by an awareness to fight for shared values as a nation-state or is it distorted by the practical interests of groups. The idea that there is a public space that can accommodate the heterogeneity of citizen's voices cannot fully be accompanied by the capacity to categorize which truth is rational. At a certain level, believing and fighting for veracity is translated as an absolute ideology. Thus, there is no other truth other than what he and his group believe to be a sign of the struggle for human rights issues in the post-Reformation era.

Understanding the character of the public sphere during and after the New Order era is the basis for seeing how social transformation occurs, not only in the consciousness of citizens, but also relating to the legitimacy of the State. Social scientists believe that the centralized and systematic model of authoritarianism as practiced by the New Order has disciplined public discourse. ${ }^{3}$ Simplification of political parties, control over the press, and even the canalization of freedom of speech are the authoritarian State strategies to present in the public sphere. Therefore, the post-new

1 Werner F Menski, "Human Rights in Southeast Asia" (2017) 1:2 Journal of Southeast Asian Human Rights 109-127.

2 Hery Prasetyo, "Sociology of Space: Sebuah Bentangan Teoritik" (2015) 7:2 Jurnal Sejarah dan Budaya 67-85.

3 Baladas Ghoshal, “Indonesia’s New Order Under Suharto” (1979) 35:4 India Quarterly 434-452. 
order era is faced with habituating citizens with differences and knowledge discourse to create social consensus.

Need to understand that those assumption is not the only way to see how submissive citizens are. Under the state centralized power, multiple layers of discourse are developed and consumed by different social groups. The idea that there is space for a discourse that is "sterile" from the detection of the State certainly invites debate. In particular, how the authoritarian system, formed by integrating the TNI-Polri power and control from within civil society, becomes the main issues that lead to the question of the lack of surveillance systems. The idea that there is space for a discourse that is "sterile" from the detection of the State certainly invites debate. In particular, how the authoritarian system, formed by integrating the military and police force and control from within civil society, can create lack of surveillance systems become the main issue. Conceptually, this puzzle can emerge from the media or educated intellectuals. This educated class networked, created discussions and even "poisoned" academician and also encourage to discuss about religion and belief as part of Human Rights issue.

The existence of the media and the educated class are part of the life of the public sphere outside the control of the State. ${ }^{4}$ The conceptual imagination of Freudian psychoanalysis can be used to see the fragility of the State. Ideas relating to the Ego and Super Ego contribute to the production of an awareness and become the basis for seeing individuals, citizens, and the State. ${ }^{5}$ Conceptually the idea of the Id imagined as will to full fill personal needs and cannot separate from the existence of the Ego. Then the ego which is imagined to be an encounter from an exclusive individual towards the inclusiveness of citizens. In other word, the ego is the subjectivities that constructed by negotiation between the self and the society. Meanwhile, the dominant presence that controls or refers to citizens seems to be the determinant force of the truth that raised before the public, which can be seen as Super Ego. The discontinuity between the Freudian elements is the educated class' way of attending to and interpreting what the media represents.

From, and within, the public sphere the educated class create a distance from state power. However, the educated class formed a formation that could not always be imagined taking a critical stance on the State. The conception of a technocratic state or, rather, the bureaucracy agents based on an educated class which line with the existence of the state, is the answer to how the educated class present with its variants.

Public awareness is filled with discourse conditioned by the State. Furthermore, the New Order established the media as the funnel for the government, so that messages addressed to the public were read in a plural manner. Public awareness, in this case, should be placed on a class structure in which the educated class is a part of

4 Effendi Gazali, "The Suharto Regime and Its fall through the Eyes of the Local Media" (2002) 64:2 Gazette (Leiden, Netherlands) 121-140.

5 Sigmund Freud, A General Introduction to Psychoanalysis, translated by G. Stanley Hall (New York: Boni and Liveright, 1922). 
the class formation. Therefore, the alignment of the educated class becomes an issue that is attached to the interests of the individual as well as represents how he was shaped by the State. In that description, the educated class can distance themselves from the authoritarian state and can be seen in three models; first is agree or defer to the state, second negotiate with the state order, and the third is vis a vis with the state domination.

The three models of articulation are the strategies to maintain their social consciousness. Then, the educated class run dynamically, where material conditions will determine to what extent the attitude consistency is taken as a strategy of social reproduction. Unfortunately, the dynamics that were conceptually imagined to be able to stain the contestation of discourse in the public sphere turned out to be covert because of the law and the state apparatus carrying out its political functions to ensure normality. Indeed there is nothing normal in the practice of authoritarian politics, but what is desired is the priority of the State through the regularity of the bureaucratic system.

Covert and cryptic is the chosen way to get out of the control of the State. Benedict Anderson, a political scientist whose academic career has focused on politics and culture in Indonesia, sees the use of the term 'Bapak,' which refers to the figure of President Soeharto, as a form of cultural 'super ego'. ${ }^{6}$ This refers to cultural dominance that can be accepted as a necessity for acts of violence and the elimination of criticism of the authorities. In this context, where culture is integrated with the State, camouflage is the best way to maintain the independence of the critical educated class.

\section{AMBIGUITY OF THE SPIRIT OF REFORM AND HUMAN RIGHTS ISSUES}

In the case of the transition of the political system in Indonesia, the celebration of critical voices no longer finds its critical form after the domination figures are replaced with a convoy of protesters. Every day the media report is always colored by fighting for the right of opinion and seeking accountability for state apparatus who are considered to be neglecting to carry out human rights. The State Apparatus became a diction that replaced the term "oknum" or person which was popular in the New Order era. By emphasizing the bureaucratic dimension, official issues are placed as part of institutional governance, where administrative or discretionary errors occur not only in individual matters but in the legal system and legislation and their derivatives regulations. ${ }^{7}$

6 Benedict Anderson, "Exit Suharto: Obituary for a Mediocre Tyrant" (2018) Konfrontasi Journal 5682.

7 Dien Vidia Rosa, "Introduction" (2021) 1:1 Journal of Contemporary Sociological Issues i-iii; Maulida Zulia Irmajayanti, Totok Sudaryanto \& Antikowati Antikowati, "Maladministration in the 
The overlapping regulations and the open expanse of interpretation allow officials to decide on actions based on the interests of their groups. The presence of individual space in public decisions becomes a new color in the life of the state. The New Order always imagined that all decisions were for the common good, then in the reform era, the word "togetherness" interpreted personally and oriented to the group interest. In this dimension, the existence of demonstrations finds its form precisely when the character of the State no longer finds the center of power.

Voicing opinions, interests and rights is part of what is discussed in the corridors of liberal democracy. Liberal in this sense needs to be translated discursively also articulately, which can be conceptualized as how individuality has a space to determine and account for its freedom as far as it is following social consensus. Furthermore, the consensus is part of the community to discuss the spirit of togetherness as a form of respect in the name of human rights defenders. Therefore, the issue of upholding democracy cannot be separated from the issue of human rights where every individual, belief or even ideology can have an inclusive dialogue.

The idea of the operation of a democratic system in which equal political rights determine common life and is imagined to be able to connect the plurality of citizens has turned into a space for the struggle for truth. Again, this is based on the loss of the center of power and the dispersal of state discourse and has been replaced by an affirmation of the spirit of the group that was silenced in the New Order era. It is interesting later when the existence of the State is translated into the dynamics of support for certain political parties, meanwhile, representatives of citizens can easily switch party identities without having to be tied to the values of the nation-state. It is an issue that continues to arise when dealing with practical politics and liberal democracy.

\section{QUESTIONING FREEDOM IN SEIZING PUBLIC AWARENESS}

Assuming the existence of freedom of Religion and Belief as a ratified diction of international regulations is a long journey to convince the public. The prefix and suffix $K e-A n$ and Ber-An are one of the key points that mark the complexity of issues relating to religion and belief. In the official Indonesian dictionary, the determination of the character, nature, and meaning behind a word relies on the presence of prefixes and suffixes in a power to create loops and relationships from an action. This means that religion is not only a matter of people's belief, but its representation and reproduction in cultural spaces becomes significant. ${ }^{8}$ At the same time, meeting and meeting other entities in a constructive sense brings harmony to life together.

Public Service: Should Government Officials be Responsible for their Decisions?” (2021) 1:1 Journal of Contemporary Sociological Issues 71-85.

8 Dien Vidia Rosa \& Hery Prasetyo, "Perempuan Islam dan Intepretasi Pos-Islamisme: Artikulasi dan Praktik Ruang Dalam Media” in Moch Nur Ichwan \& Muhammad Wildan, eds, Islamisme dan PosIslamisme dalam Dinamika Politik Indonesia Kontemporer (Yogyakarta: SUKA-Press, 2019) 155. 
In the preface, the issue of placing the State outside the shadow of the State based on religion continues to be drawn into the realm of politics and law. In Indonesia, Religion is largely understood in relation to the Sanskrit language, meaning to keep away from chaos. Alternatively, Derrida ${ }^{9}$ traces "Religion" back to its Latin origins, meaning rethinking. Given the differences associated with its linguistic root, and the powerfully emotive sentiments attached to religion, it has always been a source of social contention and even conflict. Of course, this breaks the normative understanding of religion as sacred and full of worship of order, whereby new interpretations are perceived as violating existing provisions.

Changes in religion have a long political history in Indonesia. The author has noted that religion has always been the subject of contention with issues ranging from the abolition of religion outside the the State, to how citizens' struggles to maintain their traditions and beliefs. ${ }^{10}$ Dina Tsalist Wildana notes the prevalence of discriminatory practices and the marginalization of beliefs in legal cases, highlighting the importance of the emancipation of religion and belief.

Emancipatory action is shaped by freedom and responsibility. With the freedom and responsibility of being a citizen, the boundary between the private and the public contributes to the social practice of religion. Nanda Saraswati presents a case for the reevaluation of individuality, moving beyond understandings that focus on an entity that can be intervened by the presence of the State in the name of social order. This new conceptualization of the individual acknowledges its positionality as part of a global problem that must be elaborated to obtain its social context. In this case, the State as a formal, legal force must be deliberate in the way it translates universal concepts to the local level, understanding its impacts on citizens.

The State and its citizens are two entities that create a social formation. They should be viewed as symmetrical in terms of power, with neither entity dominating or excluding the other. As such, Nella Sumika Putri contends that legal violations require a comprehensive reading, with particular attention to expert opinions. Sensitive cases, especially those related to freedom of religion and belief, are transformed into a form of public consumption. They are the subject of significant social pressure by both witnesses and experts.

Once again, the difference in the direction of discourse between religion and belief is the root of legal and political debate. Based on this, Maximus Regus highlights the

9 Jacques Derrida \& Gianni Vattimo, Religion: Cultural Memory in the Present, translated by David Webb (United States of America: Stanford University Press, 1998).

10 Clifford Geertz, The Religion of Java (Glencoe: Free Press, 1960); Niels Mulder, Mysticism in Java: ideology in Indonesia, 2nd ed ed (Yogyakarta: Kanisius, 2005); Robert W Hefner, Hindu Javanese: Tengger Tradition and Islam (New Jersey: Princeton University Press, 1985); Mark R Woodward, Islam in Java: Normative Piety and Mysticism in the Sultanate of Yogyakarta (United States of America: Assn for Asian Studies Inc, 1989); Andrew Beatty, Varieties of Javanese Religion: An Anthropological Account, Cambridge Studies in Social and Cultural Anthropology (Cambridge: Cambridge University Press, 1999). 
need for a conception of the 'intellectual'. Intellectuals, as a theoretical conception, cannot be separated from the subject and the historicity that leads to public debate. The New Order played a centralized, assertive, and intellectual position that could be matched by an educated class. Although not entirely correct, Gramsci's ${ }^{11}$ framework of thinking can be used to place social settings for intellectuals who are simultaneously part of a social class.

Intellectuals, as part of a social class, serve to absorb, translate, and articulate common interests. Not only as part of a tradition that has lost its social functions, are intellectuals actually meant to build a link between tradition and social obsession for a dialogical life. In this context, organizing and finding new social spaces is a critical challenge for amplifying the voice of.

The network that was formed in the post-reform era posed a serious challenge to intellectualism. There has been a shift from street politics, which is full of short-term practical needs, to virtual politics. ${ }^{12}$ There is no longer certain who is represented, there is only visuality and text that spreads across the internet, becoming viral. The network is duplicated by digital machines and driven by the connectedness of private space through social media. This is a powerful and urgent issue thatr must be explored further in relation to freedom of religion and belief.

The digitalization of public space without public literacy becomes a new issues in human rights Studies. Otto Gusti Ndegong Madung has philosophically engaged with the struggle between the foundation human rights and local landscapes of the knowledge in Indonesia. Philosophical readings of the encounter between the universal and the local in Kantian schools of thought highlights the cosmopolitan movement whereby a rule can both convince local beliefs and contextualize the universal. For Madung, improving the democracy index requires reflection. Civil rights and individual political rights are stagnant, but improving institutional infrastructure represents a critical point for the development of a more substantial democracy.

\section{AGAINST THE SHRINKING OF PUBLIC SPACE BY REINFORCING MULTICULTURAL DISCOURSE}

The discourse of multiculturalism is characterized by images of communities living together in an inclusive manner. In practice, multiculturalism is faced with pragmatic challenges, brought about by the ultra-liberal spirit. In today's conditions, the rise of network society and social media are also marked by the existence of a silent majority

11 Antonio Gramsci, Selections from the Prison Notebooks, Quintin Hoare \& Geoffrey Nowell Smith, eds (New York: International Publishers Co, 1971).

12 Hery Prasetyo, “Cyberpanoptic: Eksperimentasi dan (Transparansi) Kuasa Pengawasan” (2013) $3: 2$ LITERASI: Indonesian Journal of Humanities 118-132. 
postmodernist model ${ }^{13}$ Simultaneously, it is characterized by a renunciation of pleasure in order to gain recognition in the banality of knowledge. This raises concerns about the future of public space.

Experimentation to gain attention is a sign of freedom in the public sphere. However, this is followed by digital reproduction, although this can be traced through digital forensics. Hendricks and Hansen ${ }^{14}$ explore the urgent issue of the abundance of information. Maintaining public awareness in the speed of information technology becomes a challenge to parse 'infostorms'. In other words, any information that comes will always be translated based on its individual capital structure. However, by looking at the roots of citizenship which continue to be interpreted according to factual needs, this can be done to maintain the nation state.

Hurriyah sees the existence of the State as an actor who creates categories for whom and what issues can appear before the public. This has severe consequences in terms of shrinking of public space. Although, in theory, the creation of private spaces cannot be fully limited, in this case, networking and rooting in the community cannot be forgotten.

Contesting the practice of freedom by taking opportunities in multicultural politics demonstrates that religion is not fully part of the power of the State. Notwithstanding, Mirza Satria Buana highlights the role of different systems of belief underpinning community life. The ancestral religion, in this case the Kaharingan Religion, is an example of an opportunity that exists within the shrinking public space. In this case, there are intellectuals who risk opposing the authority of the State in their interpretation of the standardized practice of freedom of religion or belief.

This book indicates that there is still a way to escape the trap of liberalism. The roots of the nation state will always be challenged through appeals to alternative foundations. Clash of Civilization are characterized by conflicting cultural formations in a development model. By convincing that the West with all of its success narratives has actually met with the simplification of the problem which Said ${ }^{15}$ sees as actually leading to political issues of omission and coercion to follow the western model of thinking.

The struggle for human rights does not mean being the West or worshiping the East. Rather, it relates to a space where intellectuals are responsible for their political choices to side with human values. Where local needs meet a global context to find friends in the face of struggle and determine a common strategy to voice resistance to silence and even the commodification of human rights principles. Reading this book is like awakening a rebellious spirit who wants clarity on the position of the State and the extent to which the public sphere provides equal opportunities to every citizen. There

13 Jean Baudrillard, In the Shadow of the Silent Majorities, new edition (New York: Semiotext (e), 1983).

14 Vincent F Hendricks \& Pelle G Hansen, Infostorms: Why do we "like"? Explaining individual behavior on the social net. (Switzerland: Copernicus, 2016).

15 Edward Said, The Myth of the "Clash of Civilizations" (Columbia Univeristy, 1998). 
is no perfect state to carry out its mandate and no citizen fully knows its social position. But creating dialogue among citizens and recommending it to the State is a way that can be done together.

\section{BIBLIOGRAPHY}

Anderson, Benedict, "Exit Suharto: Obituary for a Mediocre Tyrant" (2018) Konfrontasi Journal 56-82.

Baudrillard, Jean, In the Shadow of the Silent Majorities, new edition (New York: Semiotext (e), 1983).

Beatty, Andrew, Varieties of Javanese Religion: An Anthropological Account, Cambridge Studies in Social and Cultural Anthropology (Cambridge: Cambridge University Press, 1999).

Derrida, Jacques \& Gianni Vattimo, Religion: Cultural Memory in the Present, translated by David Webb (United States of America: Stanford University Press, 1998).

Freud, Sigmund, A General Introduction to Psychoanalysis, translated by G. Stanley Hall (New York: Boni and Liveright, 1922).

Gazali, Effendi, "The Suharto Regime and Its Fall Through the Eyes of the Local Media” (2002) 64:2 Gazette (Leiden, Netherlands) 121-140.

Geertz, Clifford, The Religion of Java (Glencoe: Free Press, 1960).

Ghoshal, Baladas, "Indonesia's New Order Under Suharto" (1979) 35:4 India Quarterly 434-452.

Gramsci, Antonio, Selections from the Prison Notebooks, Quintin Hoare \& Geoffrey Nowell Smith, eds (New York: International Publishers Co, 1971).

Hefner, Robert W, Hindu Javanese: Tengger Tradition and Islam (New Jersey: Princeton University Press, 1985).

Hendricks, Vincent F \& Pelle G Hansen, Infostorms: Why do we "like"? Explaining individual behavior on the social net. (Switzerland: Copernicus, 2016).

Irmajayanti, Maulida Zulia, Totok Sudaryanto \& Antikowati Antikowati, "Maladministration in the Public Service: Should Government Officials be Responsible for their Decisions?” (2021) 1:1 Journal of Contemporary Sociological Issues 71-85.

Menski, Werner F, "Human Rights in Southeast Asia” (2017) 1:2 Journal of Southeast Asian Human Rights 109-127.

Mulder, Niels, Mysticism in Java: ideology in Indonesia, 2nd ed ed (Yogyakarta: Kanisius, 2005). 
Prasetyo, Hery, "Cyberpanoptic: Eksperimentasi dan (Transparansi) Kuasa Pengawasan” (2013) 3:2 LITERASI: Indonesian Journal of Humanities 118-132.

—_, "Sociology of Space: Sebuah Bentangan Teoritik" (2015) 7:2 Jurnal Sejarah dan Budaya 67-85.

Rosa, Dien Vidia \& Hery Prasetyo, "Perempuan Islam dan Intepretasi Pos-Islamisme: Artikulasi dan Praktik Ruang Dalam Media" in Moch Nur Ichwan \& Muhammad Wildan, eds, Islamisme dan Pos-Islamisme dalam Dinamika Politik Indonesia Kontemporer (Yogyakarta: SUKA-Press, 2019) 155.

Rosa, Dien Vidia, "Introduction” (2021) 1:1 Journal of Contemporary Sociological Issues i-iii.

Said, Edward, The Myth of the "Clash of Civilizations" (Columbia Univeristy, 1998).

Woodward, Mark R, Islam in Java: Normative Piety and Mysticism in the Sultanate of Yogyakarta (United States of America: Assn for Asian Studies Inc, 1989).

Hery Prasetyo is a lecturer at the Department of Sociology, University of Jember. He obtained Bachelor of Social Science from Airlangga University (2007) and Master of Sociology at the same university in 2010. He has joined the Centre for Human Rights, Multiculturalism, and Migration (CHRM2) since October 2020. His area of interest and works include cultural sociology, postcolonialism, subaltern studies, also globalization and development. He was a visiting scholar at SOAS University of London in December 2019-March 2020 and presented a number of papers at international conferences and has published articles in several journal. 